\title{
Upaya Meningkatkan Prestasi Belajar Akuntasi dengan Menerapkan Strategi Pembelajaran Demontrasi
}

\author{
Nasrip $^{(1)}$ \\ ${ }^{1}$ SMKN 2 BLITAR \\ Email: ${ }^{1}$ nasripeskada@gmail.com \\ DOI: https://doi.org/10.28926/riset_konseptual.v2i4.80
}

\begin{abstract}
ABSTRAK
Tujuan penelitian ini adalah untuk meningkatkan prestasi belajar mata diklat Akuntansi setelah diterapkannya strategi pembelajaran demonstrasi pada siswa kelas X Akuntansi SMK Negeri 2 Blitar. Penelitian ini termasuk penelitian tindakan kelas dengan dua siklus. Subyek penelitian ini adalah siswa kelas X Akuntansi berjumlah 36 orang. Instrumen penelitian yang digunakan dalam penelitian ini adalah lembar observasi, praktik mengerjakan siklus akuntansi dan tes. Data penelitian dikumpulkan dengan teknik observasi, wawancara dan dokumentasi. Hasil penelitian menunjukkan bahwa melalui pembelajaran demontrasi dalam pembelajaran akuntansi siswa kelas $\mathrm{X}$ akuntansi dapat meningkat secara signifikan.
\end{abstract}

Kata kunci: siklus akuntansi, demonstrasi, akuntansi.

\section{PENDAHULUAN}

Dalam mencapai Tujuan Pembelajaran Khusus pada mata pelajaran Akuntansi di Sekolah Menengah Kejuruan, khususnya di kelas $X$ masih banyak mengalami kesulitan. Hal ini terlihat dari masih rendahnya nilai mata Pelajaran Akuntansi dibandingkan dengan nilai beberapa mata pelajaran lainnya, mata pelajaran Akuntansi peringkat nilainya menempati urutan paling bawah dari mata pelajaran yang lainnya, bertitik tolak dari hal tersebut di atas perlu pemikiran-pemikiran dan tindakantindakan yang harus dilalukan agar siswa dalam mempelajari konsep-konsep Akuntansi tidak mengalami kesulitan, sehingga tujuan pembelajaran khusus yang dibuat oleh guru mata pelajaran Akuntansi dapat tercapai dengan baik dan hasilnya dapat memuaskan semua pihak.

Oleh sebab itu penggunaan metode pembelajaran dirasa sangat penting untuk membantu siswa dalam memahami konsep-konsep Akuntansi. Metode pembelajaran jenisnya beragam yang masing-masing memiliki kelebihan dan kelemahan, maka pemilihan metode yang sesuai dengan topik atau pokok bahasan yang akan diajarkan harus betul-betul dipikirkan oleh guru yang akan menyampaikan materi pelajaran. Sedangkan penggunaan metode demonstrasi diharapkan dapat meningkatkan aktivitas siswa dalam proses belajar mengajar sehingga dalam proses belajar mengajar itu aktivitasnya tidak hanya didominasi oleh guru, dengan demikian siswa akan terlibat secara fisik, emosional dan intelektual yang pada gilirannya diharapkan konsep perubahan benda yang diajarkan oleh guru dapat dipahami oleh siswa.

Berdasarkan uraian dari latar belakang tersebut di atas maka dalam penelitian in memilih judul "Upaya Meningkatkan Prestasi Belajar Akuntansi Dengan menerapkan Strategi Pembelajaran Demonstrasi Pada Siswa Kelas X Tahun Pelajaran 2011/2012". Berdasarkan latar belakang di atas, maka dapat dirumuskan suatu masalah sebagai berikut, bagaimanakah peningkatan prestasi belajar mata diklat Akuntansi dengan diterapkannya metode demonstrasi dan bagaimanakah pengaruh metode demostrasi terhadap motivasi belajar siswa.

Tujuan Penelitian, sesuai dengan permasalah diatas, penelitian ini bertujuan untuk mengetahui peningkatan prestasi belajar mata diklat Akuntansi setelah diterapkannya strategi pembelajaran demonstrasi pada siswa kelas $X$ tahun pelajaran 2011/2012, mengetahui pengaruh motivasi belajar mata diklat Akutansi setelah 
diterapkan strategi pembelajaran demonstrasi pada siswa kelas $X$ tahun pelajaran 2011/2012, menyempurnakan pelaksanaan pembelajaran mata diklat Akuntansi dalam meningkatkan prestasi belajar pada kelas $X$ tahun pelajaran 2011/2012.

\section{METODE}

Penelitian ini menggunakan pendekatan kualitatif. Jenis penelitian ini adalah penelitian tindakan kelas (Classroom Action Research). PTK merupakan proses pengkajian melalui sister berdaur yang terdiri dari 4 tahab yaitu : (1) rencana tindakan, (2) pelaksanaan tindakan, (3) observasi dan (4) refleksi. Lokasi penelitian merupakan tempat di mana penelitian dapat melihat melihat fakta-fakta yang terjadi pada saat proses KBM (Kebiatan Belajar Mengajar) berlangsung. Penelitian ini dimulai pada bulan Agustus sampai Oktober semester ganjil 2011 di SMK Negeri 2 Blitar. Teknik pengumpulan data adalah : (1) lembar pengelolaan pembelajaran oleh guru, (2) lembar aktivitas peserta didik, (3) lembar penilaian hasil belajar peserta didik dan (4) lembar persepsi peserta didik. Proses pengumpulan data dalam penelitian ini menggunakan teknik sebagai berikut : tes, observasi, angket dan dokumentasi.

Data hasil belajar siswa dianalisis dari aspek kognitif dan afektif. Penarikan kesimpulan dilakukan terhadap hasil penafsiran dan evaluasi yang sudah diperoleh, pencarian arti dan pemaknaan kata (refleksi) untuk memperoleh kesimpulan akhir. Dari kesimpulan akhir dilakukan refleksi untuk menentukan atau menyusus rencana tindakan kelas berikut nya.

Analisis data untuk mengetahui peningkatan prestasi siswa. Data peningkatan prestasi belajar yang berupa hasil tes tiap akhir siklus dianalisis dengan cara membandingkan dengan rata-rata skor tes setelah diberi tindakan (baik siklus I maupun siklus II), tanpa menggunakan analisis statistik.

Penelitian ini menggunakan standar minimal yang telah ditetapkan oleh SMK Negeri 2 Blitar yaitu 75. Seorang siswa dianggap tuntas belajarnya apabila siswa tersebut telah menyelesaikan sekurang-kurang $75 \%$ dari tujuan pembelajaran yang harus dicapai.

\section{HASIL}

Melalui hasil penelitian ini menunjukkan bahwa strategi pembelajaran demonstrasi memiliki dampak positif dalam meningkatkan prestasi belajar siswa. Hal ini dapat dilihat dari semakin mantapnya pemahaman siswa terhadap materi yang disampaikan guru (ketuntasan belajar meningkat dari siklus I dan II) yaitu masingmasing $75 \%$ dan $86,11 \%$ pada siklus II ketuntasan belajar siswa secara klasikal telah tercapai.

Berdasarkan analisis data, diperoleh aktivitas siswa dalam proses belajar mengajar dengan menerapkan strategi pembelajaran demonstrasi dalam setiap siklus mengalami peningkatan. Hal ini berdampak positif terhadap prestasi belajar siswa yaitu dapat ditunjukkan dengan meningkatnya nilai rata-rata siswa pada setiap siklus yang terus mengalami peningkatan.

Berdasarkan analisis data, diperoleh aktivitas siswa dalam proses pembelajaran akuntansi pada pokok bahasan / kompetensi mengelola entri jurnal dengan pembelajarsan kontekstual model pengajaran demonstrasi yang paling dominan adalah belajar dengan mendemonstrasikan bagi individu siswa, mendengarkan/memperhatikan penjelasan guru dan diskusi antara siswa/antara siswa dengan guru. Jadi dapat dikatakan bahwa aktivitas siswa dapat dikategorikan aktif

Sedangkan untuk aktivitas guru selama pembelajaran telah melaksanakan langkah-langkah kegiatan belajar mengajar dengan menerapkan pengajaran konsektual model pengajaran demonstrasi dengan baik. Hal iniu terlihat dari aktivitas guru yang muncul di antaranya aktivitas membimbing dan mengamati siswa dalam menemukan konsep, menjelaskan materi yang sulit, - 394 -opic- 394 - umpan balik/evaluasi/Tanya jawab dimana prosentase untuk aktivitas di atas cukup besar. 
Vol. 2 No. 4, Oktober 2018;

\section{PEMBAHASAN}

Suatu pokok bahasan / kompetensi atau sub pokok bahasan / sub kompetensi dianggap tuntas secara klasikal jika siswa yang mendapat nilai 70 lebih dari atau sama dengan $85 \%$ sedangkan seorang siswa dinyatakan tuntas belajar pada pokok bahasan / kompetensi atau sub pokok bahasan / sub kompetensi tertentu jika mendapat nilai minimal 70.

Siklus ITahap Perencanaan peneliti mempersiapkan pembelajaran yang terdiri dari rencana pelajaran 1 , soal tes formatif 1 dan alat-alat pengajaran yang mendukung. Selain itu juga dipersiapkan lembar observasi pengelolahan strategi pembelajaran demonstrasi dan lembar observasi aktivitas guru dan siswa.

Tahap kegiatan dan Pelaksanaan kegiatan belajar mengajar untuk siklus I dilaksanakan pada tanggal 4 Agustus 2011 di kelas X Akuntansi dengan jumlah siswa 36 siswa. Dalam hal ini peneliti bertindak sebagai pengajar, sedangkan yang bertindak sebagai pengamat adalah seorang guru Akuntansi dan Wali kelas X Akuntansi. Adapun proses belajar mengajar mengacu pada rencana pelajaran yang telah dipersiapkan. Pengamatan (observasi) dilaksanakan bersamaan dengan pelaksanaan belajar mengajar.

Pada akhir proses belajar mengajar siswa diberi tes formatif I dengan tujuan untuk mengetahui keberhasilan siswa dalam proses belajar mengajar yang telah dilakukan. Adapun data hasil penelitian pada siklus I adalah sebagai berikut:

Berdasarkan topik diatas aspek-aspek yang mendapatkan kurang baik adalah memotivasi siswa, menyampaikan tujuan pembelajaran, pengelolaan waktu. Ketiga aspek yang mendapat penilaian kurang baik di atas, merupakan suatu kelemahan yang terjadi pada siklus I. dan akan dijadikan bahan kajian untuk refleksi dan revisi yang akan dilakukan pada siklus II.

Berdasarkan topik di atas tampak bahwa aktivitas guru yang paling dominan pada siklus I adalah umpan balik dan, membimbing dan mengamati siswa dalam menemukan konsep yaitu 18,33 dan 15,00 \%. Aktivitas lain yang persentasenya cukup besar menjelaskan materi yang sulit dan menjelaskan materi yang sulit yaitu $13,33 \%$. Sedangkan aktivitas siswa yang paling dominant adalah mengerjakan / memperhatikan penjelasan guru yaitu $18,75 \%$. Aktivitas lain yang persentasenya cukup besar adalah bekerja dengan anggota kelompok, diskusi antar siswa dengan guru, dan membaca bukup yaitu masing-masing 18,13\%, 14, 38\% dan $11,86 \%$

Pada siklus I, secara garis besar kegiatan belajar mengajar dengan strategi pembelajaran demonstrasi sudah dilaksanakan dengan baik, walaupun peran guru masih cukup dominan untuk memberikan penjelasan dan arahan karena model tersebut masih dirasakan baru oleh siswa.

Rekapitulasi Hasil Tes Formatif Siswa Pada Siklus I

\begin{tabular}{|c|l|c|}
\hline No & \multicolumn{1}{|c|}{ Uraian } & Hasil Siklus I \\
\hline 1 & Nilai rata-rata tes formatif & 75 \\
2 & Jumlah siswa yang tuntas belajar & 29 \\
3 & Prosentase ketuntasan belajar & 50 \\
\hline
\end{tabular}

Dari di atas dapat dijelaskan bahwa dengan menerapkan strategi pembelajaran demonstrasi diperoleh nilai rata-rata presentasi belajar siswa adalah 75 dan ketuntasan belajar mencapai $75 \%$ atau ada 27 siswa dari 36 siswa sudah tuntas belajar. Hasl tersebut menunjukkan bahwa pada siklus pertama secara klasikal siswa belum tuntas belajar, karena siswa yang memperoleh nilai $\geq 70$ hanya sebesar $75 \%$ lebih kecil dari persentase ketuntasan yang dikehendaki yaitu sebesar $85 \%$. Hal ini disebabkan karena siswa masih merasa baru dan belum mengerti apa yang dimaksud dan digunakan guru dengan menerapkan strategi pembelajran demonstrasi. Refleksi dan pelaksanaan kegiatan belajar mengajar diperoleh informasi dari hasil pengamatan sebagai berikut Guru perlu lebih terampil dalam memotivasi siswa dan lebih jelas 
Vol. 2 No. 4, Oktober 2018;

dalam menyampaikan tujuan pembelajaran. Di mana siswa diajak untuk terlibat langsung dalam setiap kegiatan yang akan dilakukan. Guru perlu mendistribusikan waktu secara baik dengan menambahkan informasi-informasi yang dirasa perlu dan catatan. Guru harus lebih terampil dan bersemangat dalam memotivasi siswa sehingga siswa bisa lebih antusias.

Siklus II Tahap perencanaan tahap ini peneliti mempersiapkan perangkat pembelajaran yang terdiri dari rencana pelajaran 2 , soal tes formatif 2 dan alat-alat pengajaran yang mendukung. Selain itu juga dipersiapkan lembar observasi pengelolaan strategi pembelajaran demonstrasi dan lembar observasi guru dan siswa. Tahap kegiatan dan pelaksanaankegiatan belajar mengajar untuk siklus II dilaksanakan dengan jumlah siswa 36 orang. Dalam hal ini peneliti bertindak sebagai pengajar, sedangkan yang bertindak sebagai pengamat adalah seorang guru Akuntansi dan Wali kelas X Akuntansi. Adapun proses belajar mengajar mengacu pada rencana pelajaran dengan memperhatikan revisi pada siklus I, sehingga kesalahan atau kekurangan pada siklus I tidak terulang lagi pada siklus II. Pengamatan (observasi) dilaksanakan bersamaan dengan pelaksanaan belajar mengajar.

Pada akhir proses belajar mengajar siswa diberi tes formatif II dengan tujuan untuk mengetahui tingkat keberhasilan siswa dalam proses belajar mengajar yang dilakukan. Instrument yang digunakan adalah tes formatif II. Aspek-aspek yang diamati pada kegiatan belajar mengajar (siklus II) yang dilaksanakan oleh guru dengan menerapkan strategi pembelajaran demonstrasi mendapatkan penilaian yang cukup baik dari pengamat adalah memotivasi siswa, membimbing siswa, merumuskan kesimpulan/menemukan konsep dan pengolahan waktu.

Penyempurnaan aspek-aspek diatas dalam menerapkan strategi pembelajran demonstrasi diharapkan dapat berhasil semaksimal mungkin. Berdasarkan pelaksanaan siklus di atas tampak bahwa aktivitas guru yang paling dominan pada siklus II adalah memberikan umpan balik yaitu 16,67\%, membimbing dan mengamati siswa dalam menemukan konsep yaitu $15,00 \%$. Jika dibandingkan dengan siklus I, aktivitas ini mengalami penurunan. Aktivitas guru yang mengalami peningkatan adalah menyampaikan materi/langkah-langkah/strategi dan -396-opic- 396 - umpan balik/evaluasi/Tanya jawab yaitu $13.33 \%$ dan $16,67 \%$.

Sedangkan untuk aktivitas siswa yang paling dominan pada siklus II adalah menulis yang relevan dengan KBM yaitu $14,57 \%$, merangkum pembelajaran $12,29 \%$ dan menyajikan hasil pembelajaran yaitu (12,08\%).

Rekapitulasi Hasil Tes Formatif Siswa Pada Siklus II

\begin{tabular}{|l|l|l|}
\hline No & Uraian & Hasil Siklus I \\
\hline 1 & Nilai rata-rata tes formatif & 25 \\
2 & Jumlah siswa yang tuntas belajar & \\
3 & prosentase ketuntasan belajar & 25 \\
\hline
\end{tabular}

Berdasarkan data diatas diperoleh nilai rata-rata tes formatif sebesar 78 dan dari 36 siswa yang telah tuntas sebanyak 31 siswa dan 5 siswa belum mencapai ketuntasan belajar (harus remidi). Maka secara klasikal ketuntasan belajar yang telah tercapai sebesar $86,1100 \%$ (termasuk kategori tuntas). Hasil pada siklus II ini mengalami peningkatan lebih baik dari siklus I. adanya peningkatan hasil belajar pada siklus II ini dipengaruhi oleh adanya peningkatan kemampuan guru dalam menerapkan strategi pembelajaran demonstrasi sehingga siswa menjadi lebih terbiasa dengan pembelajaran seperti ini sehingga siswa lebih mudah dalam memahami materi yang telah diberikan.

Refleksi, tahap ini akan dikaji apa yang telah terlaksana dengan baik maupun yang masih kurang baik dalam proses belajar mengajar dengan penerapan strategi pembelajran demonstrasi Dari data-data yang telah diperoleh dapat diuraikan sebagai berikut: 
Vol. 2 No. 4, Oktober 2018;

Selama proses belajar mengajar guru telah melaksanakan semua pembelajaran dengan baik. Meskipun ada beberapa aspek yang belum sempurna, tetapi persentase pelaksanaannya untuk masing-masing aspek cukup besar. Berdasarkan data hasil pengamatan diketahui bahwa siswa aktif selama proses belajar berlangsung. Kekurangan pada siklus-siklus sebelumnya sudah mengalami perbaikan dan peningkatan sehingga menjadi lebih baik. Hasil belajar siswa pada siklus III mencapai ketuntasan.

Revisi Pelaksanaanada siklus III guru telah menerapkan pembelajaran demonstrasi dengan baik dan dilihat dari aktivitas siswa serta hasil belajar siswa pelaksanaan proses belajar mengajar sudah berjalan dengan baik. Maka tidak diperlukan revisi terlalu banyak, tetapi yang perlu diperhatikan untuk tindakan selanjutnya adalah memaksimalkan dan mempertahankan apa yang telah ada dengan tujuan agar pada pelaksanaan proses belajar mengajar selanjutnya penerapan strategi demonstrasi dapat meningkatkan proses belajar mengajar sehingga tujuan pembelajaran dapat tercapai.

\section{KESIMPULAN}

Strategi pembelajaran demonstrasi dapat meningkatkan kualitas pembelajaran Akuntansi, memiliki dampak positif dalam meningkatkan prestasi belajar siswa yang ditandai dengan peningkatan ketuntasan belajar siswa dalam setiap siklus, yaitu siklus I (75\%), dan siklus II $(86,11 \%)$ serta dapat menjadi siswa merasa dirinya mendapat perhatian dan kesempatan untuk menyampaikan pendapat, gagasan, ide dan pertanyaan.

\section{SARAN}

Agar proses belajar mengajar Akuntansi lebih efektif dan lebih memberikan hasil yang optimal bagi siswa, maka untuk melaksanakan strategi pembelajaran demonstrasi memerlukan persiapan yang cukup matang, sehingga guru harus mampu menentukan atau memilih topik yang benar-benar bisa diterapkan dengan pembelajaran kontektual model pengajaran demonstrasi dalam proses belajar mengajar sehingga diperoleh hasil yang optimal.

Dalam rangka meningkatkan prestasi belajar siswa, guru hendaknya lebih sering melatih siswa dengan berbagai metode pengajaran, walau dalam taraf yang sederhana, dimana siswa nantinya dapat menemukan pengetahuan baru, memperoleh konsep dan keterampilan, sehingga siswa berhasil atau mampu memecahkan masalah-masalah yang dihadapinya.

\section{DAFTAR RUJUKAN}

Ali, Muhammad. 1996. Guru Dalam Proses Belajar Mengajar. Bandung. Sinar Baru Algesindo.

Arikunto, Suharsimi. 1993. Manajemen Mengajar Secara Manusiawi. Jakarta: Rineka Cipta.

Arikunto, Suharsimi. 2001. Dasar-dasar Evaluasi Pendidikan . Jakarta. Bumi Aksara

Arikunto, Suharsimi. 2002. Prosedur Penelitian Suatu Pendekatan Praktek. Jakarta: Rikena Cipata

Azhar, Lalu Muhammad. 1993. Proses Belajar Mengajar Pendidikan. Jakarta: Usaha Nasional.

Daraeso, Bambang. 1989. Dasar dan Konsep Pendidikan Moral Pancasila. Semarang: Aneka IImu

Hadi, Sutrisno. 1982. Metodologi Research, Jilid I. Yogyakarta: YP Fak. Psikologi UGM Hasibuan. J.J., \& Moerdjiono. 1998. Proses Belajar mengajar. Bandung: Remaja Rosdakarya.

Margono, 1997. Metodologi Penelitian Pendidikan. Jakarta: Rineksa Cipta.

Masriyah, 1999. Analisis Butir Tes. Surabaya: Universitas Terbuka Press

Ngalim, Purwanto M. 1990. Psikologi Pendidikan. Bandung: Remaja Rosdakarya. 
JURNAL PENDIDIKAN: Riset \& Konseptual

Vol. 2 No. 4, Oktober 2018;

Nur, Moh. 2001. Pemotivasian Siswa Untuk Belajar. Surabaya: Universitas Negeri Surabaya.

Purwodarminto. 1991. Strategi Belajar Mengajar. Jakarta: Bina Aksara 